\title{
溶存酸素制御によるマヨネーズの酸化防止 \\ Protection against Oxidation in Mayonnaise by the Control of Dissolved Oxygen
}

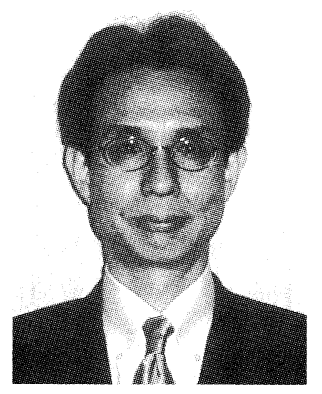

小林英明

キューピー株式会社 研究所 于183-0034

東京都府中市住吉町 5-13-1

Hideaki KOBAYASHI

R\&D Division, Q.P.Corporation 5-13-1, Sumiyoshi-Cho, Fuchu-Shi,

Tokyo, 183-0034, JAPAN

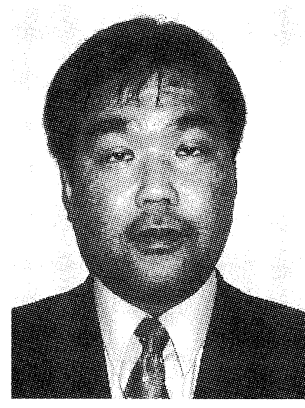

高宮 満

キューピー株式会社 研究所 T183-0034

東京都府中市住吉町 5-13-1

Mitsuru TAKAMIYA R\&D Division, Q.P.Corporation 5-13-1, Sumiyoshi-Cho, Fuchu-Shi,

Tokyo, 183-0034, JAPAN

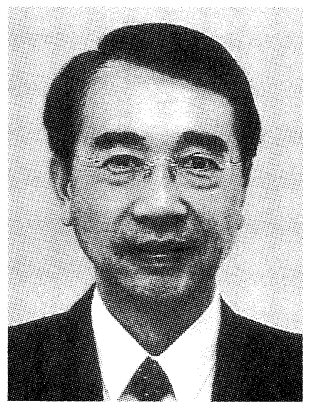

長谷川 峯夫

キューピー株式会社 研究所 ₹183-0034

東京都府中市住吉町 5-13-1

Mineo HASEGAWA R\&D Division, Q.P.Corporation 5-13-1, Sumiyoshi-Cho, Fuchu-Shi, Tokyo, 183-0034, JAPAN

論文要旨：各種の食品が, 空気中の酸素によって酸化されることにより風味劣化を起こすことは広く知ら れている。マヨネーズは水中油型乳化食品であり，植物油，卵黄など多価不飽和脂肪酸を含む脂質成分が配 合されており，しかも卵黄由来の鉄イオンも豊富に含むため，酸化による品質劣化が起こりやすい食品であ る。そこで，海外で市販されている製品では EDTA などの酸化防止郕を配合し酸化劣化を防ぐことが一般的 となっている。一方，日本でのマヨネーズ製造 80 年の歴史においては，製造工程や容器包材に扔いて徹底的 な酸素遮断を行うことでほぼ品位の安定した製品を作ってきた。

しかし, 食品の風味は非常に微妙であり，ごくわずかずつではあるが，やはり若干の酸化劣化は進行して いる。いらでも，どんな場面でもマヨネーズをよりおいしく拄様に味わっていただきたいと考えた時，溶 存酸素（DO）に着目した。食品中の DO 制御技術は，ビール，コーヒー，牛乳などの微妙な風味を大切にす る飲料分野では導入されている例があるが，マヨネーズなどの高粘性の乳化食品については，従来技術的に 容易ではなく一般的ではなかった。

そこで，まず高粘性の乳化食品の DO 測定法を検討し，非破壊蛍光式溶存酸素計を用いることで DO 測定 を可能とした。次に，液体原料の DO を予め $\mathrm{N}_{2}$ バブリング法にて下げ，他工程でも酸素巻き込みをさせない ことでマヨネーズ充填直後の DO を低い範囲に制御する製造工程を可能とした。こうすることで，マヨネー ズなど高粘性の乳化食品においても，DO 制御技術により長期保存中の酸化劣化を今まで以上に防げること を確認した。

この DO 制御技術は，2002 年 12 月よりキユーピーマヨネーズにおいて導入され，お客様にマヨネーズの おいしさをより楽しんでいただけるようになった。 


\begin{abstract}
Mayonnaise is an oil-in-water emulsion formulated with egg yolk and vegetable oil. Since the oil is high in polyunsaturated fatty acids, mayonnaise is very susceptible to oxidation and subsequent loss of quality. In countries other than Japan, the addition of EDTA has been implemented to prevent the oxidation of mayonnaise. However, we in Japan have been testing alternative methods of preventing oxidation by controlling the amount of oxygen from outside through the packaging.

Since this oxygen control alone cannot maintain the long-term quality of mayonnaise, we have studied the effects of controlling the level of dissolved oxygen (DO). However, this method has not been used in a high-density emulsified food before. In this study, we first measured the amount of DO in mayonnaise with a non-invasive fluorescence type DO sensor. Next, we produced mayonnaise with various levels of DO. Finally we analyzed the amount of DO and the flavor of the mayonnaise.

As a result, we confirmed that without the addition of an antioxidant such as EDTA, we could avoid the oxidation during storage of mayonnaise by controlling the level of DO.
\end{abstract}

Key words: Mayonnaise, Oxidation, Dissolved Oxygen, EDTA, Non-Invasive Fluorescence Type DO Sensor

\section{1 はじめに}

マヨネーズは, 食用植物油脂と卵黄と醸造酢などを主 要原料として乳化した $\mathrm{o} / \mathrm{w}$ エマルションであり, 代表 的な乳化食品の一つである。使用できる原料は「農林物 資の規格化及び品質表示の適正化に関する法律（JAS 法)」におけるドレッシングの品質表示基準に制定され ており，定められた原材料以外のものを使用した場合， マヨネーズと呼ぶことができない文。卵黄型マヨネーズ の配合一例を Table 1 に示した。

マヨネーズの発祥は, 1700 年代地中海に浮かぶメノ ルカ島（現スペイン）にまでさかのぼる説”が有力であ る。人類が鷄卵を食べるようになり, 卵黄と液状の植物 油を混ぜて乳化することを発見した。ここで得られたマ ヨネーズソースは半固体状であり, 液状油を半固体状に 加工することでさらに油脂のおいしさを引き出した加工 食品ともいえる。

この卵黄型マヨネーズは，おいしさだけでなく栄養面 からも優れた役割がある。それは, 植物油由来の一価不 飽和脂肪酸（オレイン酸）をはじめ, 卵黄に含まれるリ ン脂質（ホスファチジルコリンなど）やこれを構成する ドコサヘキサエン酸やアラキドン酸などの多価不飽和脂 肪酸, 近年眼の健康を保つ成分として注目を集めている ルテイン ${ }^{3)}$ などのカロテノイド類, また普段の食事から 撕りにくい貴重なミネラルであるカルシウムや鉄などの 微量機能成分を豊富に含んでいることである。また，こ

Table 1 Formulation Example of Mayonnaise (Egg Yolk Type)

\begin{tabular}{lr}
\hline Vegetable Oil & $70 \mathrm{~g}$ \\
Egg Yolk & $15 \mathrm{~g}$ \\
Vinegar & $12 \mathrm{~g}$ \\
Others (Salt etc.) & $3 \mathrm{~g}$ \\
\hline
\end{tabular}

れらが数 $\mu \mathrm{m}$ レベルの微細な $\mathrm{o} / \mathrm{w}$ エマルションとして 掑取されることで，良好な吸収性も期待される。

さらに最近では，この卵黄型マヨネーズが野菜の力を 引き出す調味料であることもわかってきた。緑黄色野菜 のカラフルな彩りをもたらすカロテノイド類は, 野菜に 含まれる重要な栄養素である。このカロテノイド類には $\beta$-カロテンなどがあり脂溶性抗酸化ビタミンともいわれ るが, 単に生野菜や野菜ジュースとして摂取した場合, 実は我々の身体にはなかなか吸収されにくい。例えばこ の $\beta$-カロテンを豊富に含むニンジンを卵黄型マヨネー ズと一緒に食べると, $\beta$-カロテンの吸収率は, ニンジン そのままやニンジンジュースに比べて有意に高まること が健常成人への投与試験で確認された には卵黄リン脂質の働きと $\mathrm{o} / \mathrm{w}$ エマルションの関与が 考えられている5

つまり卵黄型マヨネーズは, それ自体各種の微量栄養 成分を豊富に含んでいる食品であるとともに，どんな食 材とも相性がよく, この食材中の微量栄養成分を効率よ く体内に取り込むことを助ける機能性調味料であるとも いえる。

\section{2 マヨネーズの酸化要因}

マヨネーズには, 以上のような優れた特性があるが, これは食品として扔いしく食べられることが前提であ る。防腐剤などを用いなくても, 原料である醸造酢や食 塩の効果により微生物的には充分長期間の保存が可能で あるが，酸化による風味の劣化に対してはやはり注意が 必要である。

一般に, 食品の酸化要因としては, 酸素, 光, 温度, 遷移金属（銅，鉄イオン）などが挙げられるが，いろい ろな原料を含む加工食品の場合には, 特にこの遷移金属 に注意が必要である。生体内の脂質過酸化反応の開始 
には, 微量鉄イオンの重要性が高いといわれるが ${ }^{6)}$, 卵 黄など食品成分の場合も同様であり，この鉄イオンが食 品中に微量存在する脂質 hydroperoxide（LOOH）をレ ドックス分解し容易にラジカルを生じ, 自動酸化の連鎖 反応を開始してしまう ${ }^{6)}$ 。

卵黄中には約 $60 \mathrm{mg} / \mathrm{kg}$ の鉄が含まれ7)，これを卵黄 配合量 $15 \%$ 卵黄型マヨネーズに換算すると約 9 $\mathrm{mg} / \mathrm{kg}$ に相当する。たとえば植物油の場合, その保存 性を半減させるのに必要な遷移金属量は, 銅 0.05 $\mathrm{mg} / \mathrm{kg}$, 鉄 $0.6 \mathrm{mg} / \mathrm{kg}$ と極微量であるといわれており ${ }^{8)}$ 。 この点からもマヨネーズの酸化要因として, 鉄イオンに 注意が必要なことがわかる。つまり, 卵黄型マヨネーズ は重要な栄養成分である鉄イオンを豊富に含む一方, 加 工食品としてその保存性を考える場合には, 酸化防止対 策が重要となる。

このような背景から, 海外で市販されているマヨネー ズにおいては, 鉄キレート効果のあるエチレンジアミン 四酢酸カルシウム二ナトリウム $(\mathrm{EDTA} \cdot \mathrm{Ca} \cdot 2 \mathrm{Na})$ など の酸化防止剂が添加される ことが一般的となってい る。

\section{3 日本におけるマヨネーズの酸化防止対策の流れ ${ }^{2)}$}

1925 （大正 14）年に，日本で初めてキユーピーマヨ ネーズが製品化されてから 80 年, すでに日本人の食卓 には欠かせない食品となっているが，この間実際市販さ れている製品における工夫を振り返りながら, 現実的な 酸化防止対策を見てみよう（Fig. 1)。

卵黄型マヨネーズの設計において，卵黄の鉄イオンは 貴重なミネラル供給源であるが, 酸化安定性の面からは 鉄イオンの㗢きを抑えこんでおきたい。しかも，できる だけ酸化防止剂などの添加物には頼りたくないと考える と, どうしても酸化の元の原因である「酸素」に注目し ていくことになる。つまり，できるだけ鮮度の良い（酸

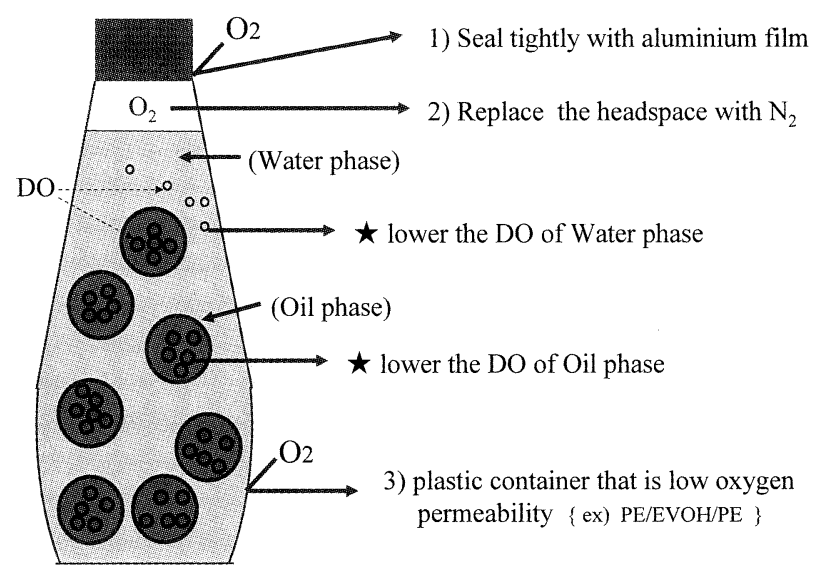

Fig. 1 The Strategy of Oxidation Stability of Mayonnaise.
化劣化していない）原料素材を用い，あとは徹底的に製 造工程や製品中から酸素を排除していくことで酸化を防 ぎ品質を保持する考え方である。

まず，マヨネーズ製造開始から間もない1926(大正 15) 年に真空ミキサーを導入し，乳化時に巻き込む酸素 を除いた。当時はガラス瓶入りであり，包材面では外部 から透過する酸素はほぼ遮断できていた。

1958 (昭和 33) 年には, フレキシブルなプラスチック 容器（ポリエチレン製）入りの市販を始めた。この新容 器導入で, ガラス瓶入りに比べ，いろいろな食の場面で 使える汎用性を高めることができた。一方でポリエチレ ンは比較的酸素透過性が高いため, 容器からの外部侵入 酸素対策が必要となった。

1972 (昭和 47) 年に, 酸素透過性の低いエチレンビニ ルアルコール樹脂（EVOH）をポリエチレン層にサンド イッチした多層容器を導入することで，ガラス瓶にほぼ 匹敵する酸化安定性を実現することができた。このフレ キシブルな多層容器の完成で, ガラス瓶では得られない 汎用使用特性と酸化安定性を同時に満たすことができる ようになり，食卓においてマヨネーズをより身近なもの とすることができた。

その後, おいしさをより保つために容器口部のアルミ シール化 $\{1988$ (昭和 63) 年\} やヘッドスペースの窒素 置換 $\{1998$ (平成 10) 年\}を行い, 外因性酸素に関して はほぼ遮断できたといえる。

ここまでの酸化防止対策で，いろいろの場面において も使いやすいフレキシブルな多層容器入りで, しかも室 温 7 カ月の賞味期間の間おいしく食べることのできる製 品を提供することができた。

\section{4 マヨネーズの溶存酸素に着目}

このように，マヨネーズという商品特性に応じた酸化 防止対策を長年講じてきたが，食品の風味というものは 非常に微妙なものである。ごくわずかずつではあるが， やはり賞味期間中において若干の酸化劣化は進行してい ると考えられた。マヨネーズは，調味料として本当にい ろいろの食材と合わせてお使いいただく場合がある。い つでも，どんな場面でも，マヨネーズをよりおいしくお 客様に味わっていただきたいと考えた時，新たな切り口 として他分野の食品, 特に嗜好品として微妙な味わいを 追求する酒類や飲料分野の動きに着目してみた。

ビール ${ }^{9)}$, 日本酒 ${ }^{10)}$, 缶コーヒー ${ }^{11)}$, 牛乳 ${ }^{12)}$ などの分 野では，微妙な風味を酸化劣化させずに維持していくた めに，製品そのものに含まれている酸素すなわち「溶存 酸素（DO）」に注目していた。このDOは，ごく微量で あっても食品成分に直接接するため重要であり, 近年こ 
の DO 制御を実用化することで本格的な味わいを追求す る製品が生まれてきている。たとえば，缶コーヒーの製 造工程に掞いては仕达み原料である水などの DO を低く 保ち，その後の抽出，乃過，充填までの工程でも酸素を 巻き达まない状態で加熱殺菌を行うなどの工夫もされて いる ${ }^{11)}$ 。またビールの場合には，そのおいしさを維持す るために製品中の DO 量が，0.1 ppm 程度と非常に低い レベルでコントロール9) されているようであった。

マヨネーズという乳化食品は, 飲料など水系溶液状食 品とは異なり，植物油を主要原料として含んでいる。実 は，Fig. 2 に示すとおり，この植物油にはその性質上， 水の約 5 倍（1気圧，大気下で約 $27 \mathrm{~mL} / \mathrm{L}$ ）もの酸素が

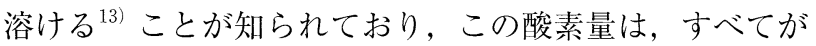
過酸化物に変化したとすると，過酸化物価 $(\mathrm{POV})=4.7$

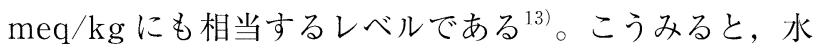
系溶液状食品以上にDO に注意を払う必要があることが わかる。

しかし，マヨネーズやドレッシングなどの半固体状乳 化物や夕ルタルソースのような具材入り乳化食品におい ては，その取り扱いにくさのためか，DOの測定や制御 方法に関して，従来あまり検討されていなかったと思わ れる。そこで我々は，まずこれら半固体乳化食品の DO をどのように計測するかを検討した。

\section{5 半固体状乳化食品の溶存酸素測定法 ${ }^{14-15}$}

\section{$5 \cdot 1$ ポーラログラフ式 DO 計（希勫法）}

ポーラログラフ式センサーは，測定原理上試料中の酸 素を消費するため, 測定液を常に擋拌しておく必要があ る。つまり測定試料の流動性が必要である。そこで予め 窒素バブリングなどの方法で調製した脱酸素水を用意 し，これで粘性の高い乳化液状ドレッシングを $2 \sim 3$ 倍 に希釈し流動性を高めて測定し, 得られた数值から希釈 倍率を用いて算出した。この方法で, 乳化液状のサウザ ンアイランドドレッシングの DO 測定が可能となった。 (Fig. 3)
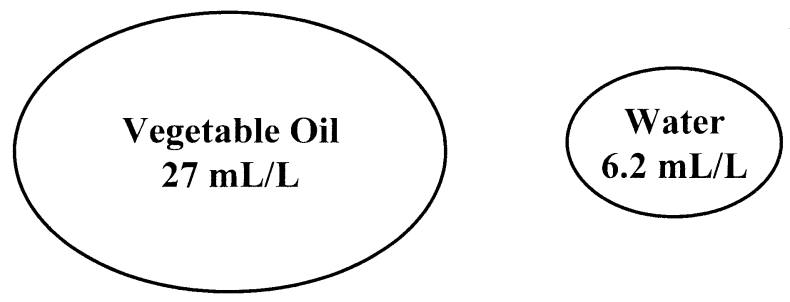

Fig. 2 The Amount of Dissolved Oxygen in Vegetable Oil and Water $\left(1 \mathrm{~atm}, 25^{\circ} \mathrm{C}\right.$, saturated in the air).

\section{$5 \cdot 2$ 非破壊蛍光式酸素計}

マヨネーズは乳化ドレッシング類よりも一般的に粘度 が高く，このため $5 \cdot 1$ ポーラログラフ式 DO 計（希釈 法）ではなかなか安定した結果が得られなかった。そこ で，なにか良い方法がないものかと探していたところ， 特殊な蛍光染料を用いて光学的に酸素濃度を測定できる センサー（アメリカ OxySense 社製 OxySense 101）が 実用化されたことを知った。

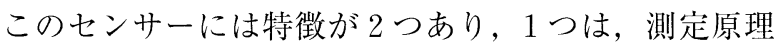
上試料中の酸素を消費しないため, 試料を動かす必要が ないこと。もう 1 つは，光を透過する食品容器であれ ば，この蛍光染料フィルムを内部に付けた状態で食品を 充填，密封することで，未開封のまま外部から光学的に 内部の酸素濃度（ヘッドスペースガス及びDO）が測定

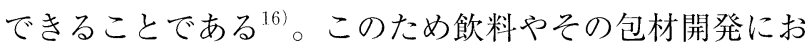
いて，その優れた特徵が活かされつつある。我々はこの センサーであれば，半固体状であるマヨネーズの DO 測 定も可能となるのではと考え応用してみた。その結果， 予めプラスチックボトル容器の内側に蛍光染料フィルム を貼り付けておき，ここにマヨネーズを充填，密封する ことで，製品保管中の経時的な DO 変化をこのセンサー で追うことができるようになった。(Fig. 4)

\section{6 マヨネーズ, ドレッシングでの溶存酸素制御 ${ }^{14-15)}$}

\section{$6 \cdot 1$ ドレッシングの DO 制御例}

植物油 $38 \%$ ，醸造酢 $6 \%$ ，卵黄 $1.2 \%$ などを配合し， ピックルスなどの固形具材も含有した乳化液状ドレッシ ングとして，サウザンアイランドドレッシングの調製例 を示军。

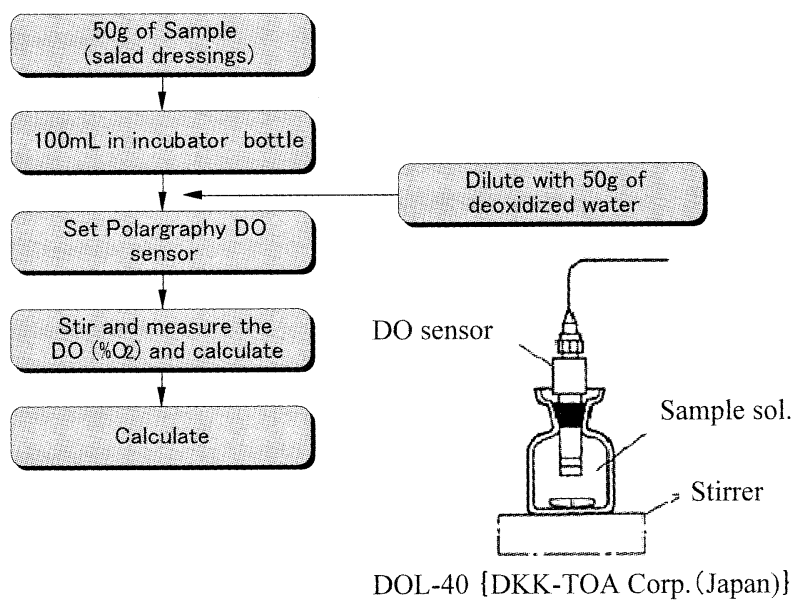

Fig. 3 The Procedure for Measuring the Amount of Dissolved Oxygen in o/w Emulsified Food Products (A) Polarography DO sensor (dilution method). 


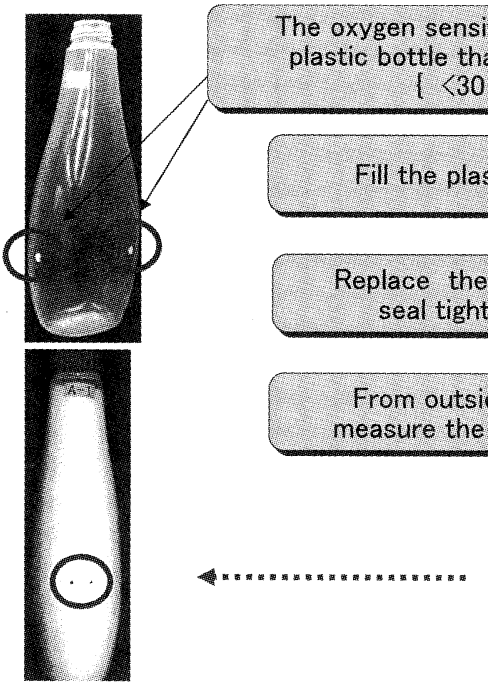

Mayonnaise in a plastic bottle $\left\langle 30 \mathrm{cc} / \mathrm{m}^{2} \cdot\right.$ day $\left.\cdot \mathrm{atm}\right\}$

Fig. 4 The Procedure for Measuring the Amount of Dissolved Oxygen in o/w Emulsified Food Products (B) non-invasive fluorescence type DO sensor.
まず，液体原料である植物油，清水，醇造酢などの DO を予め低減する。これは，一般に原料が 1 気圧の大 気に接した状態では，ほぼその条件下で飽和 DO（分 圧：20.9\% $\mathrm{O}_{2}$ ） に平衡化しているため， $\mathrm{N}_{2}$ バブリング 処理を行い $2.0 \% \mathrm{O}_{2}$ まで DO を減じた。次に，植物油以 外の原料を真空ミキサー中に入れて混合し，続いて少量 ずつ植物油を加え真空下 $(20 \mathrm{kPa})$ で乳化を行う。さら に $65^{\circ} \mathrm{C}$ で 30 分間加熱殺菌を行い，外気を巻き込まない ように手早く細口のガラス瓶に $200 \mathrm{~mL}$ ずつ充填し, ヘッドスペースを $\mathrm{N}_{2}$ 置換した後密封した（低 DO 区）。 対照として, 植物油, 清水, 醉造酢の DO が高い状態で 同様に試作したもの（高 DO 区）とこれに酸化防止剂と して EDTA·Ca·2 Naを $100 \mathrm{mg} / \mathrm{kg}$ 添加したもの（EDTA 区）を同様に調製した。
これらの DO 挙動を, 乳化終了時 (加熱殺菌前), 加 熱殺菌・充填直後, $35^{\circ} \mathrm{C}$ 遮光保存で $3,7,10$ 週間後の 計 5 点について，5·1 に示したポーラログラフ式 DO 計 （希釈法）を用いて測定し，合わせて官能評価も行った。

Fig. 5 に示すとおり，高 DO 区と EDTA 区は，乳化終 了時でそれぞれ約 $15,13 \% \mathrm{O}_{2}$ の高い DO 值を示し，加 熱殺菌の前後にて $3 \% \mathrm{O}_{2}$ 程度の酸素消費が見られた。 その後 $35{ }^{\circ} \mathrm{C}$ 保存， 3 週間後で急激にDO が低下し $2-3 \%$ $\mathrm{O}_{2}$ レベルとなり，10 週間後にはほぼ完全にDO が消費 されていた。一方，低 DO 区では乳化終了時で $4.0 \% \mathrm{O}_{2}$ 程度であり， $35^{\circ} \mathrm{C}$ 保存， 7 週間後までほとんど変化な く，最終的に 10 週間後でほぼ完全にDO が消費されて いた。

外部から侵入する酸素がほぼ無いとすると，加熱殺菌

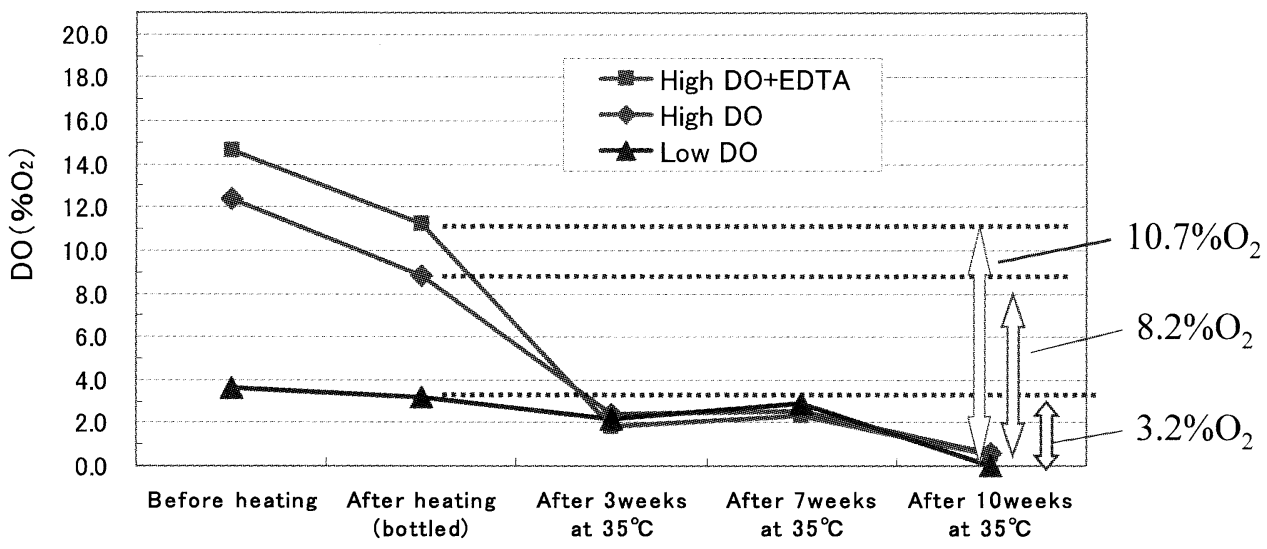

Fig. 5 Dissolved Oxygen Concentration Profile in Emulsified Salad Dressing During Storage at $35^{\circ} \mathrm{C}$ for 10 Weeks without Light. 
後ガラス瓶に密封されてから $35^{\circ} \mathrm{C}$ 保存, 10 週間後まで の全 DO 消費量が容器内のドレッシングの酸化に消費さ れた酸素量となる。この消費酸素量は, 低 DO 区が $3.2 \% \mathrm{O}_{2}$ であったのに対し, 高 DO 区，EDTA 区は 8.2，10.7\% $\mathrm{O}_{2}$ となり差が見られた。これら 10 週間後の 試料を官能評価してみると，EDTA 区はキレート効果 により良好な風味を維持していたが, 高 DO 区は製品特 有の風味が減じるとともに酸化臭が感じられた。一方低 DO 区は，ほぼ良好な風味を維持して扔り，合成のキ レート揧を用いなくても, DO 制御により風味が維持で きることが確認できた。

EDTA 区に関しては，酸素消費によりドレッシング 中で一次酸化生成物であるハイドロパーオキサイドは増 加するものの, キレート効果により鉄イオンが不活化さ れることで，アルデヒド類など二次酸化生成物への変化 が抑えられ風味劣化が抑えられていると考えられた。

\section{$6 \cdot 2$ マヨネーズのDO 制御例}

次に植物油 $72.5 \%$ ，醸造酢 $10 \%$ ，卵黄 $7.2 \%$ を配合し たマヨネーズの調製例を示す。

$6 \cdot 1$ サウザンアイランドドレッシングの場合とほぼ 同様に，液体原料の DO を予婤整することで，低 DO 区と高 DO 区の試料を調製した。ただし，マヨネーズの 場合は, 真空ミキサーで粗乳化後, コロイドミルで仕上 げ乳化を行い，外気を巻き达まないように手早く細口の プラスチック製多層容器（酸素透過性 $30 \mathrm{cc} / \mathrm{m}^{2} \cdot \mathrm{day} \cdot$

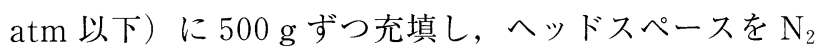
置換した後，アルミシールで口部を密封した。これらを $5^{\circ} \mathrm{C}$ にて 1 週間遮光保存し, その後温度を $20^{\circ} \mathrm{C}$ とし約 7 週間後まで保存を続けた。その際の DO 挙動を5.2 に示 した非破壞蛍光式酸素計にて測定した。

その結果, Fig. 6 に示すとおり, $5^{\circ} \mathrm{C}, 1$ 週間保存にお いては高 DO 区と低 DO 区ともにほとんど酸素消費が見 られなかった。すなわち, 家庭の冷蔵庫内に近い保存温 度帯ではほとんどマヨネーズの自動酸化は進行しにくい ということが，直接ボトル内の DO 測定により確認され

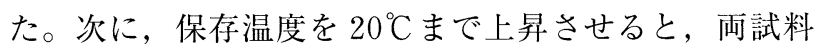
ともに急激な DO 低下が見られ $20^{\circ} \mathrm{C}$ において 2,3 週間 でほぼ定常化していた。

プラスチック製多層容器の外部から侵入する酸素がほ ぼ無いとすると, 保存 7 週間までにこのマヨネーズの酸 化で消費された酸素量は，低 DO 区が $4.7 \% \mathrm{O}_{2}$ であった のに対し，高 DO 区は $8.7 \% \mathrm{O}_{2}$ となり，約 $4 \% \mathrm{O}_{2}$ の差 が見られた。すなわち, 乳化ドレッシングの場合と同様 に，製造直後の製品 DO を低く保つ製造条件をとること で, 製品保存中の酸化劣化を極力抑えることができると 考えられた。

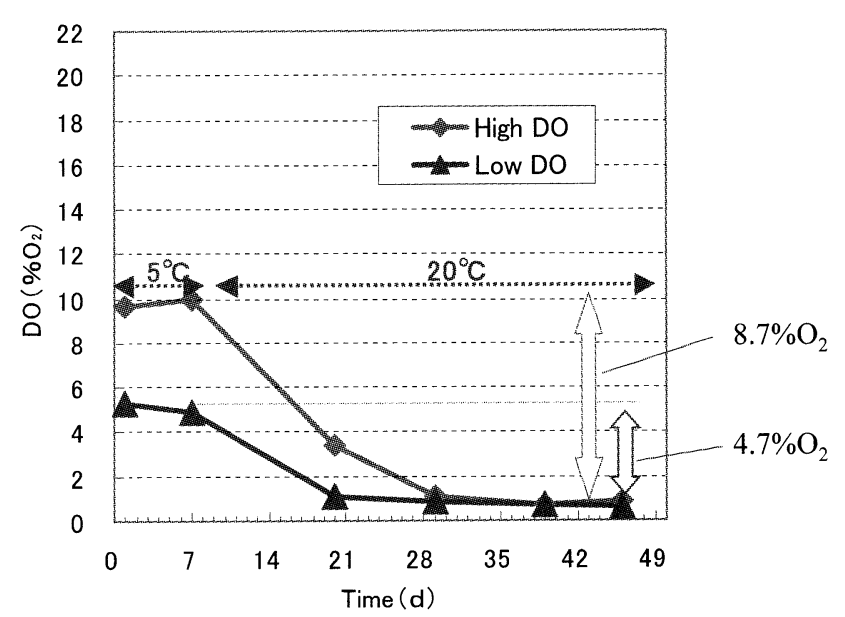

Fig. 6 Dissolved Oxygen Concentration Profile in Real Mayonnaise During Storage at $5 \rightarrow 20^{\circ} \mathrm{C}$ for 46 Days Without Light.

\section{7 おわりに}

従来酒類，飲料など水系溶液食品分野で先端的に導入 されてきた DO 制御の考え方は，なるべく添加物などに 頼らない自然にやさしい品質保持技術の一つとして重要 と考えられた。しかし，この考え方をマヨネーズ，ド レッシングなど半固体状で，しかも酸素の溶けやすい油 脂を主要原料として含む乳化食品において実現する上で は，新たな DO 計測法の工夫と品質評価技術が必要で あった。

一般には，できるだけ食品中の DO を下げることが酸 化劣化を防ぐうえで重要と考えられるが，一方で微妙な 味わいに微量酸素が重要な働きを果たす場合がある。す なわち，今回我々が扱ったマヨネーズなどの場合にも， 過度にDO を低下させると醸造酢のッンとした刺激臭が やや強くなり，味のバランスが崩れる場合があった。こ のため，微妙なおいしさを設計していくためには，対象 となる食品に応じて細かな DO 制御が必要とされると思 われる。

キューピーマヨネーズにおいては，このDO に着目し た考え方を導入し， 2002 年 12 月より「おいしさロング ラン製法」として実用化した（Fig. 1)。そして，ポリボ トル入り製品の賞味期間も常温で 7 カ月から 10 カ月に 延長され，お客様により長い期間おいしさを楽しんでい ただけるようになった（Fig. 7，8）。

先に述べたように, 海外のマヨネーズにおいては, EDTA な゙の添加物による品質保持が一般的となって いるが，日本のマヨネーズに抏いては，今回述べたよう な独自の酸化防止アプローチを行ってきたといえる。し かし, 食品のおいしさを追求していく上では,「酸素」 との戦いに終わりはなく，また新たな創意工夫も必要で 


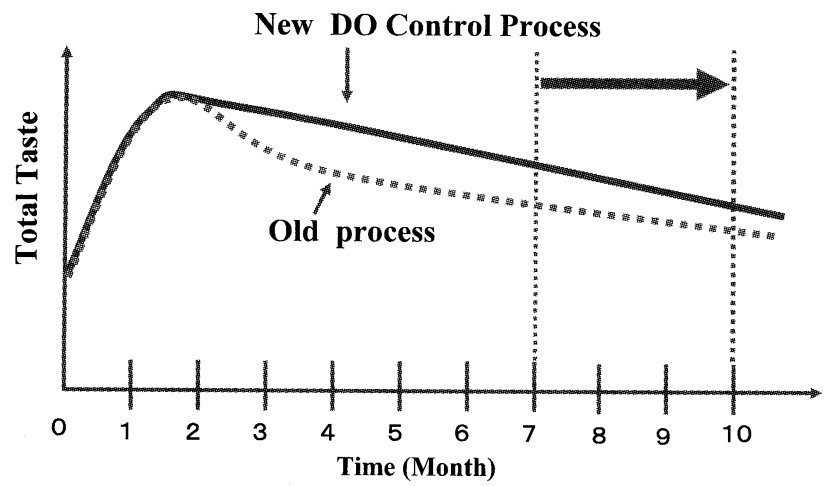

Fig. 7 Taste profile in Kewpie's Real Mayonnaise (Egg Yolk Type) During Storage at $25^{\circ} \mathrm{C}$ for 10 Months.

\section{あろう。}

DO 制御による品質保持技術は, 非常にシンプルな考 え方であるので, 従来取り入れられていなかった加工食 品や医薬品, 化粧品など他分野にも今後応用が期待され る。

\section{文献}

1）農林水産省総合食品局品質課, 農林物資の規格化及び 品質表示の適正化に関する法律，中央法規出版, (2002).

2）小林幸芳, マヨネーズ・ドレッシング入門, 日本食糧 新聞社, (2005).

3) G.J. Handelman, Z.D. Nightingale, A.H. Lichtenstein, E.J. Schaefer \& J.B. Blumberg, Am. J. Clin. Nutr., 70, 247-51 (1999).

4）圓島蘭子，竹内綾子，増田泰伸，久能昌朗，長谷川峯夫， 丸山千寿子，第 59 回 日本栄養·食糧学会大会 (2005).

5）瀧澤佳津枝, 荻野裕司, 木村守, 増田泰伸, 久能昌朗, 長谷川峯夫, 日本農芸化学会 2004 年度大会.

6) 寺尾純二, 油化学, 41, 750-6 (1992).

7）科学技術庁資源調査会編, 五訂 日本食品成分表, 女子

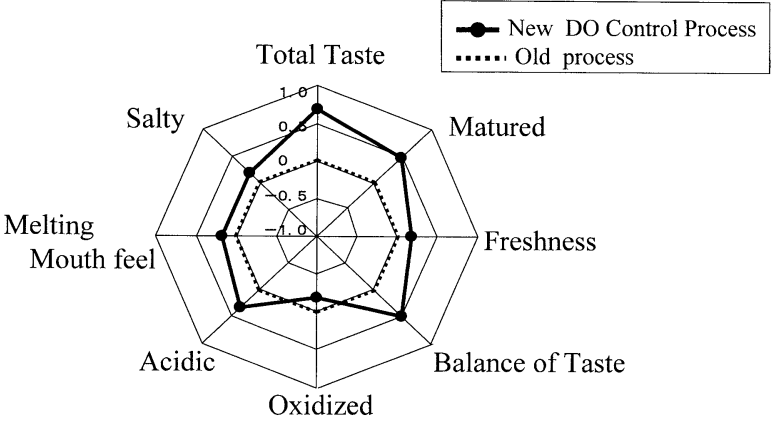

Fig. 8 Results of Sensory Scores for Kewpie's Real Mayonnaise (Egg Yolk Type) after Storage at $25^{\circ} \mathrm{C}$ for 10 Months.

栄養大学出版部, p.258 (2005).

8）太田静行，食品と酸化防止剂，(株)食品資材研究会，p.19 (1987).

9）篠塚健，高塩仁愛，金田弘挙，山岸信久, 日本農芸化 学会誌, 74, 967-73 (2000).

10）石原直樹，岡本匡史，平岡信次，川北貞夫，中村輝也, 特開平 10-313850.

11）玉置洋司，六鹿靖務，浅野浩司，早川義信，特許第 2747867 号.

12）稲垣宏樹，伊藤啓人，大久保絢子，久保田康史，平田 寿友，中坪正，見城尚義，特許第 3083798 号.

13）安田耕作，食用油とその生産，幸書房，p.174-6 (1992).

14）小林英明, 有泉雅弘, 重松康彦, 高宮満, 松田始, 坂 部展久，再公表 WO 2003/077677.

15) H. Kobayashi, M. Ariizumi, H. Matsuda, N. Sakabe, Y. Shigematsu \& M. Takamiya, Effect of dissolved oxygen on oxidation of Mayonnaise, 95 th AOCS Annual Meeting \& Expo. 2004, Cincinnati, USA.

16) Draaijer, A. et al., A novel optical method to determine oxygen in beer bottles, EBC congress 1999, Cannes, France. 